\title{
ATG5 wt Allele
}

National Cancer Institute

\section{Source}

National Cancer Institute. AT G5 wt Allele. NCI Thesaurus. Code C104963.

Human AT G5 wild-type allele is located in the vicinity of $6 \mathrm{q} 21$ and is approximately $141 \mathrm{~kb}$

in length. This allele, which encodes autophagy protein 5 , is involved in autophagy and may be involved in apoptosis. 